\title{
AUTOTRANSFUSION IN CORONARY ARTERY BYPASS GRAFTING: DISPARITY IN LABORATORY TESTS AND CLINICAL PERFORMANCE
}

\author{
Hanne I. Flom-Halvorsen, $\mathrm{PhD}^{\mathrm{a}, \mathrm{b}}$ \\ Eivind $\emptyset_{\text {vrum, }} \mathrm{MD}, \mathrm{PhD}^{\mathrm{a}}$ \\ Geir Tangen, $\mathrm{MD}^{\mathrm{a}}$ \\ Frank Brosstad, MD, $\mathrm{PhD}^{\mathrm{b}}$ \\ Mari-Anne L. Ringdal, CCPa \\ Rolf Øystese, CCPa
}

Objective: Autotransfusion during and after cardiac surgery is widely performed, but its effects on coagulation, fibrinolysis, and inflammatory response have not been known in detail. Methods: Hemostatic and inflammatory markers were extensively studied in $\mathbf{4 0}$ coronary artery bypass patients undergoing a consistent intraoperative and postoperative autotransfusion protocol. An identical autotransfusion protocol was applied to 4916 consecutive coronary patients and the overall clinical results were evaluated in this large patient population. Results: The autologous blood pooled before bypass remained nearly inactivated after storage. A slight elevation of thrombin-antithrombin complex and prothrombin fragment 1.2 , as well as plasmin/ $\alpha_{2}$-antiplasmin complex was found in the content of the extracorporeal circuit after surgery, indicating thrombin formation and fibrinolytic activity. Also some increase of $\beta$-thromboglobulin was present. In the mediastinal shed blood, complete coagulation, as evidenced by the absence of fibrinogen, had taken place and all parameters described above were extremely elevated. However, no thrombin activity was detected. As for the inflammatory response, moderately increased levels of complement activation products, terminal complement complex, and interleukin-6 traced in the extracorporeal circuit reached very high levels in mediastinal shed blood. Autotransfusion of the residual extracorporeal circuit blood and the mediastinal drainage was followed by elevation of most of these markers in circulating plasma. On the other hand, no correlating harmful effects were recorded in the study patients or in the consecutive 4916 patients. Coagulation disturbances were rare and allogeneic transfusions were required in fewer than $4 \%$ of all patients. Conclusions: The hemostatic and immunologic systems were moderately activated in the autologous blood remaining in the extracorporeal circuit, whereas the mediastinal shed blood was highly activated in all aspects. However, autotransfusion had no correlating clinical side-effects and the subsequent exposure to allogeneic blood products was minimal. (J Thorac Cardiovasc Surg 1999;118:610-7)
$T^{\prime}$ ransfusion of autologous blood during cardiac surgery has routinely been practiced for more than 2 decades as part of a strategy to minimize the use of allo-

\footnotetext{
From the Department of Cardiac Surgery, Oslo Heart Center, ${ }^{a}$ Research Institute for Internal Medicine, University of Oslo, Rikshospitalet, ${ }^{\mathrm{b}}$ Oslo, Norway.

Received for publication Oct 20, 1998; revisions requested Dec 16, 1998; revisions received June 14, 1999; accepted for publication June 15, 1999.

Address for reprints: Eivind $\emptyset_{\mathrm{v} r u m}, \mathrm{MD}, \mathrm{PhD}$, Oslo Heart Center, Pilestredet 32, N-0027 Oslo, Norway.

Copyright (C) 1999 by Mosby, Inc.

$0022-5223 / 99 \$ 8.00+0 \quad \mathbf{1 2 / 1 / 1 0 0 7 4 2}$
}

geneic blood and blood products. Apart from being a restricted resource, transfusion of bank blood carries the risks of serious complications: isoimmunization, hemolytic and allergic reactions, immunosuppression, graft-versus-host disease, and transfusion-transmitted viral diseases such as human immunodeficiency virus/ acquired immunodeficiency syndrome, hepatitis, and cytomegalovirus infection. ${ }^{1}$ The use of allogeneic blood has also been shown to be a risk factor for postoperative infection after coronary artery bypass grafting. ${ }^{2}$

Several autotransfusion techniques have evolved and major blood conservation achievements have been accomplished by predonation of autologous blood, ${ }^{3}$ 
prebypass removal of autologous blood with isovolumetric substitution, ${ }^{4}$ reinfusion of the volume remaining in the extracorporeal circuit, ${ }^{5}$ and postoperative autotransfusion of the shed mediastinal drainage blood. ${ }^{6-10}$ However, the effects of autotransfusion on biologic cascades have not been investigated in detail. The present study reports on the effects of autotransfusion on sensitive markers for activation of coagulation, fibrinolysis, platelets, and the immunologic system, both in the autotransfused blood at different time points and in patients during and after autotransfusion. The subsequent clinical consequences of the autotransfusion protocol applied to a large patient population are reviewed.

\section{Patients and methods}

Patients. From 1989 through 1997, 4956 consecutive patients underwent myocardial revascularization with a heartlung machine in our department. The majority of the patients underwent surgery on an elective basis. Only $1.7 \%$ had repeat operations. Some types of patients were taken care of by a neighboring university department, such as patients with severe renal dysfunction, patients in need of a combined carotid and coronary operation, and those facing true emergencies such as failed angioplasties. Otherwise, a typical population of patients undergoing coronary artery bypass was treated (Table I). All patients, without any exclusions, underwent a consistent blood conservation protocol, previously described in detail. ${ }^{11}$ The main steps included (1) removal of autologous blood before cardiopulmonary bypass (CPB) for retransfusion after $\mathrm{CPB}$ (in patients with normal preoperative red cell volume), (2) intraoperative retransfusion of oxygenator and tubing contents, and (3) postoperative autotransfusion of shed mediastinal blood up to 18 hours after the operation.

In a subset of 40 randomly selected male patients electively admitted for coronary artery bypass grafting (study group), a series of laboratory tests was performed. Exclusion criteria included anticoagulation, antiplatelet therapy administered less than 7 days before the operation, and unstable angina. Also patients with an estimated hematocrit value less than $22 \%$ during CPB were excluded because of removal of substantial blood samples. When eligible, the study patients were selected during a 5-month period, being the first patients on the operation program. This was done because of logistic reasons, to be able to sample and handle all the blood specimens. The study protocol for these patients was approved by the regional ethics committee and informed consent was obtained from all patients.

The total patient population except for the 40 patients in the study group are referred to as the main group.

\section{Operation}

All patients. During the entire period under investigation (1989-1997), the treatment strategies have remained unchanged in all major aspects. More than two thirds of the patients were operated on by one of two surgeons. The anes-
Table I. Demographic and operative data of the main group $(n=4916)$ and the study group $(n=40)$

\begin{tabular}{llcc}
\hline & Main group & Study group & P value \\
\hline Age (y) & $63(56-69)$ & $64(55-69)$ & .2 \\
Female proportion (\%) & 16.4 & - & - \\
Patients with previous MI & 55.1 & 52.5 & .9 \\
$\quad(\%)$ & & & \\
Ejection fraction (\%) & $70(60-77)$ & $72(64-80)$ & .2 \\
Left main stenosis (\%) & 19.3 & 7.5 & .1 \\
Diabetes (\%) & 8.6 & 12.5 & .2 \\
At least 1 ITA graft (\%) & 99.1 & 100 & .2 \\
No. of distal anastomoses & $4(3-5)$ & $5(3.5-5)$ & .03 \\
Ischemic time (min) & $32(25-39)$ & $31(25-36)$ & .4 \\
ECC (min) & $57(46-67)$ & $52(44-60)$ & .02
\end{tabular}

There were no statistically significant intergroup differences, except for exclusion of women in the study group and small differences concerning number of distal anastomoses and time of extracorporeal circulation. Median values are given, with quartiles in parentheses. MI, Myocardial infarction; ITA, internal thoracic artery; $E C C$, extracorporeal circulation.

thesia protocol was designed to permit early postoperative extubation and included mainly a combination of diazepam $(0-0.2 \mathrm{mg} / \mathrm{kg})$, midazolam hydrochloride $(0-0.2 \mathrm{mg} / \mathrm{kg})$, fentanyl $(6-8 \mathrm{mg} / \mathrm{kg})$, and pancuronium bromide supplemented with isoflurane and nitrous oxide.

Autologous blood was withdrawn before CPB from all patients in whom the estimated hemodilution on $\mathrm{CPB}$ was expected to exceed a hematocrit value of $22 \%$. After heparinization and insertion of the cannulas, blood was drained by gravity into blood bags and stored at room temperature for retransfusion at the conclusion of CPB. To prevent hemodynamic instability, the blood volume removed was replaced with the priming solution through the aortic cannula.

If available, at least one internal thoracic artery was grafted, supplemented with saphenous vein grafts. Surgical hemostasis was completed before reversal of the anticoagulation with protamine sulphate at a ratio of $1.3 \mathrm{mg}$ of protamine to $1 \mathrm{mg}$ of heparin. The residual CPB circuit blood from the oxygenator and the tubing set was drained into blood bags and retransfused in the operating room or in the intensive care unit. For postoperative autotransfusion of mediastinal shed blood, the mediastinal and pleural tubes were connected to the hard-shell cardiotomy reservoir used during extracorporeal circulation, and the blood was retransfused hourly through a $20-\mu \mathrm{m}$ infusion filter. Normovolemic anemia was accepted to a hematocrit value of $25 \%$ after the operation; a level below this was considered an indication for allogeneic red blood cell transfusion. No antifibrinolytic drug or other agents to reduce bleeding were routinely given.

Study group. Blood samples were drawn with a syringe from the central venous cannula, discarding the first $10 \mathrm{~mL}$, at the following intervals: (1) after induction of anesthesia, (2) immediately after termination of CPB but before administration of protamine, (3) 1 hour after the operation, (4) 2 hours after the operation, (5) 4 hours after the operation, and 
(6) 18 hours after the operation. As the mediastinal drainage volume was retransfused every hour, the postoperative blood sample time points were chosen to detect possible direct effects of the autotransfusion.

In vitro blood was withdrawn with a syringe via a 3-way stopcock, which was connected to the blood bags and the cardiotomy reservoir. The samples were harvested at the following intervals: (1) from the pre-CPB pooled autologous blood immediately before retransfusion, after termination of $\mathrm{CPB}$, (2) from the residual CPB-circuit blood directly before retransfusion, and (3-5) from the mediastinal shed blood immediately before retransfusion 1,2 , and 4 hours after the operation.

Blood specimens from the patients and the in vitro blood were injected into (1) EDTA K3 Vacutainer tubes (15\%, 0.34 mol/L) (Becton Dickinson \& Co, Rutherford, NJ) for complement/cytokine analysis and platelet count, (2) sodium citrate tubes ( $1 / 10$ volume of $0.129 \mathrm{~mol} / \mathrm{L}$ ) (Becton Dickinson) for coagulation, fibrinolysis, and heparin analysis, and (3) DiatubeH tubes (Diagnostica Stago, Asnieres-sur-Seine, France) for $\beta$-thromboglobulin ( $\beta$-TG) determination. All specimens, except those for whole-blood platelet count, were immediately cooled with ice slush and centrifuged as soon as possible: EDTA Vacutainer tubes: $1500 g, 10$ minutes, $4^{\circ} \mathrm{C}$; sodium-citrate Vacutainer tubes: $1500 \mathrm{~g}, 10$ minutes, room temperature; heparin 2000-4000g, 20 minutes, $4^{\circ} \mathrm{C}$; DiatubeH tubes: $2500 \mathrm{~g}, 30$ minutes, $4^{\circ} \mathrm{C}$. Plasma samples were stored at $-70^{\circ} \mathrm{C}$ until assayed.

Analyses. The thrombin-antithrombin (TAT) complex, the prothrombin fragment $1.2\left(\mathrm{PF}_{1.2}\right)$, and the plasmin $/ \alpha_{2}-$ antiplasmin (PAP) complex were all assayed with the use of an enzyme-linked immunoassay according to the instructions given by the manufacturer (Enzygnost TAT/F1+2/PAP micro, Behringwerke AG, Diagnostica, Marburg, Germany).

Detection of thrombin in mediastinal shed blood was determined as follows: Citrated supernatant from centrifuged shed blood $(100 \mu \mathrm{L})$ was added to purified human fibrinogen (200 $\mu \mathrm{L}, 2 \mathrm{mg} / \mathrm{mL}$ of Tris-HCl buffer, $\mathrm{pH}$ 7.4). The mixture was observed at $37^{\circ} \mathrm{C}$ for 20 minutes for potential clot formation.

The platelet activation marker $\beta$-TG was measured with an enzyme-linked immunosorbent assay as described by the manufacturer (Asserachrom $\beta$-TG, Diagnostica Stago).

Fibrinogen concentration was determined according to the method of Clauss. ${ }^{12}$

NycoCard D-dimer immunoassay (Nycomed Pharma, Oslo, Norway) was used for determination of D-dimer.

Total plasma heparin was determined by a chromogenic anti-FXa assay (Coatest Heparin, Chromogenix AB, Mölndal, Sweden).

For measurement of the heparin cofactor activity of antithrombin, a chromogenic assay was used in accordance with the manufacturer's instructions (Coamatic Antithrombin, Chromogenix AB).

The concentration of plasma free hemoglobin was measured by a colorimetric method according to Hunter, GroveRasmussen, and Soutter ${ }^{13}$ modified by us for use on Titertek Twinreader PLUS device (Labsystems Oy, Helsinki, Finland).
Platelet count was determined with an automatic cell counter (Cobas Minos ST; Roche, Basel, Switzerland).

Protein $\mathrm{C}$ was determined in the supernatant from centrifuged shed blood samples with a chromogenic assay (Coamatic Protein C, Chromogenix AB). Appropriate blanks were made from each supernatant, subtracting blank values before calculations of results.

The concentration of the fluid-phase terminal complement complex (TCC) was measured according to the method of Mollnes and associates, ${ }^{14}$ which is based on a double-antibody enzyme-linked immunosorbent assay with monoclonal antibodies specific for a neoantigen of polymeric $\mathrm{C} 9$.

The $\mathrm{C} 3$ activation products $(\mathrm{C} 3 \mathrm{bc}$ ) were quantified in a double-antibody enzyme-linked immunosorbent assay described by Garred, Mollnes, and Lea, ${ }^{15}$ using monoclonal antibodies specific for the $\mathrm{C} 3$ neoepitope expressed on $\mathrm{C} 3 \mathrm{~b}$, $\mathrm{iC} 3 \mathrm{~b}$, and $\mathrm{C} 3 \mathrm{c}$ as capture antibody.

An immunoenzymometric assay (EASIA; enzyme amplified sensitivity immunoassay) was used for the quantitative measurement of the cytokine tumor necrosis factor $\alpha$ and the cytokine interleukin-6 in accordance with the manufacturer's instructions (Medgenix, Diagnostics, Fleurus, Belgium).

Statistics. The data are presented as median with quartiles. Longitudinal changes between 2 time points only were analyzed using the paired Student $t$ test. Linear regression analysis was used to test the statistical correlation between the measured laboratory data from the patients 4 hours after the operation (after having received the major part of the retransfused blood) and the values in the mediastinal shed blood 2 hours after the operation. All data during CPB are given uncorrected for hemodilution. All data were recorded prospectively and stored in a database.

\section{Results}

Study group. Demographic and operative data were similar to the main group population except for exclusion of female gender and a slight difference in $\mathrm{CPB}$ time (Table I). All patients had autologous blood withdrawn before CPB for retransfusion after CPB (Table II). The amount of autotransfusion of mediastinal shed blood was smaller in the study group than in the main group $(P=.01)$, mainly due to blood sampling from the reservoir. The clinical course was uneventful in all patients (Table III). There were no incidents of postoperative myocardial infarction or stroke, and all patients survived. No allogeneic blood products were given. Antifibrinolytic drugs were not administered to any patient.

Autologous blood withdrawal. The heparinized autologous blood withdrawn before CPB was stored at room temperature during the time of extracorporeal circulation, that is, for about 1 hour. Some activation of platelets was assessed by a statistically significant elevation of the levels of $\beta$-TG to a median of $83 \mathrm{IU} / \mathrm{mL}$ 
Table II. Blood conservation data in the main group $(n=4916)$ and the study group $(n=40)$

\begin{tabular}{lccc}
\hline & Main group & Study group & P value \\
\hline $\begin{array}{c}\text { Autologous blood } \\
\text { removal before CPB } \\
(\mathrm{mL})(\mathrm{n}=4232)\end{array}$ & $880(600-1050)$ & $1000(800-1060)$ & .07 \\
$\begin{array}{c}\text { Mediastinal drainage } \\
\quad 6 \text { hours postop }(\mathrm{mL})\end{array}$ & $650(525-820)$ & $560(500-720)$ & .1 \\
$\begin{array}{c}\text { Autotransfusion of } \\
\text { shed blood (mL) }\end{array}$ & $630(505-800)$ & $468(413-645)$ & .01 \\
$\begin{array}{c}\text { Resternotomy for } \\
\text { bleeding (patients) }\end{array}$ & $149(2.9 \%)$ & 0 & \\
$\begin{array}{c}\text { RBC transfusion } \\
\quad+/ \text {-plasma) (patients) }\end{array}$ & $113(2.3)$ & 0 & \\
$\begin{array}{c}\text { Plasma or platelet } \\
\text { transfusion (patients) }\end{array}$ & $56(1.2 \%)$ & 0 & \\
$\begin{array}{c}\text { Preop Hgb } \\
\text { concentration (gm/L) }\end{array}$ & $146(137-153)$ & $146(143-153)$ & .5 \\
$\begin{array}{c}\text { Hgb concentration at } \\
\text { discharge (gm/L) }\end{array}$ & $120(110-130)$ & $117(113-128)$ & .9 \\
\hline
\end{tabular}

Values are given as median values with quartiles in parentheses. $C P B$, Cardiopulmonary bypass; $R B C$, red blood cell; $H g b$, hemoglobin.

(51-120 IU/mL) compared with the preoperative level of $31 \mathrm{IU} / \mathrm{mL}(24-37 \mathrm{IU} / \mathrm{mL})(P<.01)$. Otherwise there was no detectable activation of coagulation, fibrinolysis, or immunologic systems.

$C P B$ circuit content. The analyses performed on the blood samples taken from the CPB circuit content immediately before retransfusion are listed in Table IV. Compared with preoperative values, coagulation and fibrinolysis studies revealed statistically significant elevation of TAT complex, $\mathrm{PF}_{1.2}, \beta-\mathrm{TG}$, and PAP complex, whereas the concentrations of antithrombin and fibrinogen were significantly decreased. Also the markers for complement activation and cytokine release were found to be significantly higher than the preoperative levels. Measurable levels of plasma free hemoglobin and heparin were found.

Mediastinal shed blood and circulating plasma. Extremely high levels of markers for thrombin and fibrin generation, as well as platelet activation, were seen in the mediastinal shed blood (Table V). Interestingly, no clotting was observed after 20 minutes' incubation of shed blood with purified human fibrinogen, excluding significant amounts of thrombin to be present. The mediastinal shed blood contained very small amounts of fibrinogen in all postoperative samples. In the circulating plasma, a statistically significant elevation of these markers was seen during and after the operation (Table VI).

A pattern similar to that seen for the coagulation system was demonstrated for fibrinolytic activity, as
Table III. Postoperative complications in the main group $(n=4916)$ and the study group $(n=40)$

\begin{tabular}{|c|c|c|c|}
\hline & Main group & Study group & $\mathrm{P}$ value \\
\hline Ventilatory support (h) & $1.5(1.0-2.0)$ & $1.7(1.1-2.2)$ & .1 \\
\hline $\begin{array}{l}\text { Reintubated after } \\
\text { extubation (patients) }\end{array}$ & $55(1.1 \%)$ & 0 & .5 \\
\hline Periop MI (patients) & $128(2.6 \%)$ & 0 & .3 \\
\hline $\begin{array}{l}\text { Postop renal failure } \\
\text { (dialysis) (patients) }\end{array}$ & $3(0.1 \%)$ & 0 & .9 \\
\hline Mediastinitis & $25(0.6 \%)$ & 0 & .7 \\
\hline $\begin{array}{l}\text { Permanent cerebral } \\
\text { dysfunction (patients) }\end{array}$ & $44(0.9 \%)$ & 0 & .6 \\
\hline $\begin{array}{l}\text { Transient neurologic } \\
\text { events (patients) }\end{array}$ & $28(0.6 \%)$ & 0 & .6 \\
\hline $\begin{array}{l}\text { Physical rehabilitation } \\
\text { within } 5 \text { days (patients) }\end{array}$ & $4558(92 \%)$ & $39(97.5 \%)$ & 1.0 \\
\hline $\begin{array}{l}\text { Hospital mortality } \\
\text { (patients) }\end{array}$ & $22(0.44 \%)$ & 0 & .7 \\
\hline
\end{tabular}

Table IV. Characteristics of the CPB circuit blood compared with preoperative levels in the patients $(n=40)$

\begin{tabular}{lccc}
\hline & Preop & CPB circuit & P value \\
\hline Heparin $(\mathrm{IU} / \mathrm{mL})$ & $0.1(0.1-0.1)$ & $4(4-5)$ & $<.001$ \\
TAT $(\mu \mathrm{g} / \mathrm{L})$ & $3.5(2.6-5.7)$ & $89(49-100)$ & $<.001$ \\
$\mathrm{PF}_{1.2}(\mathrm{nmol} / \mathrm{L})$ & $1.0(0.8-1.5)$ & $4.3(3.0-5.2)$ & $<.001$ \\
$\beta-\mathrm{TG}(\mathrm{IU} / \mathrm{mL})$ & $31(24-37)$ & $270(200-400)$ & $<.001$ \\
PAP $(\mu \mathrm{g} / \mathrm{L})$ & $410(290-470)$ & $780(450-1400)$ & $<.001$ \\
Antithrombin $(\%)$ & $100(92-100)$ & $62(54-71)$ & $<.001$ \\
Fibrinogen $(\mathrm{g} / \mathrm{L})$ & $3.0(2.7-4.0)$ & $1.8(1.6-2.1)$ & $<.001$ \\
$\mathrm{pHgb}(\mathrm{g} / \mathrm{dL})$ & $0(0-0.01)$ & $0.05(0.04-0.07)$ & .9 \\
$\mathrm{IL}-6(\mathrm{pg} / \mathrm{mL})$ & $6.2(4.5-8.6)$ & $29(18-41)$ & $<.001$ \\
TNF- $\alpha(\mathrm{pg} / \mathrm{mL})$ & $14(12-18)$ & $19(14-22)$ & $<.001$ \\
TCC $(\mathrm{AU} / \mathrm{mL})$ & $4.0(3.0-5.0)$ & $77(49-130)$ & $<.001$ \\
$\mathrm{C} 3 \mathrm{bc}(\mathrm{AU} / \mathrm{mL})$ & $9.0(7.5-11)$ & $80(61-120)$ & $<.001$ \\
\hline
\end{tabular}

Values are given as median values with quartiles in parentheses. Heparin, Total plasma heparin; TAT, thrombin-antithrombin complex; $P F_{1.2}$, prothrombin fragment $1.2 ; \beta-T G, \beta$-thromboglobulin; $P A P$, plasmin- $\alpha_{2}$-antiplasmin complex; $p H g b$, plasma free hemoglobin; $I L-6$, interleukin-6; $T N F-\alpha$, tumor necrosis factor $\alpha$; TCC, terminal complement complex; $C 3 b c, \mathrm{C} 3$ activation products.

assessed by PAP complex in the mediastinal shed blood, as well as in circulating plasma (Tables $\mathrm{V}$ and VI). Fibrinolytic activity in the mediastinal shed blood was further evidenced by high and increasing levels of fragment $\mathrm{D}$-dimer during the postoperative time.

Elevated concentrations of plasma free hemoglobin were seen in the mediastinal shed blood and increased slightly during the 4 postoperative hours (Table V). No significant changes in plasma free hemoglobin in circulating plasma occurred during and after the opera- 
Table V. Characteristics of the mediastinal shed blood in the study group $(n=40)$ during the 1 st, $2 n d$, and 4 th postoperative hours

\begin{tabular}{lccc}
\hline & 1 st hour & 2nd hour & 4th hour \\
\hline Heparin $(\mathrm{IU} / \mathrm{mL})$ & $0.1(0.1-0.2)$ & $0.1(0.1-0.1)$ & $0.1(0.1-0.1)$ \\
TAT $(\mu \mathrm{g} / \mathrm{L})$ & $21,000(14,000-25,000)$ & $23,000(18,000-28,000)$ & $25,000(20,000-30,000)$ \\
$\mathrm{PF}_{1.2}(\mathrm{nmol} / \mathrm{L})$ & $430(280-540)$ & $430(310-560)$ & $340(230-550)$ \\
$\beta-\mathrm{TG}(\mathrm{IU} / \mathrm{mL})$ & $5,100(3,300-7,300)$ & $5,200(4,000-6,800)$ & $5,500(3,800-6,700)$ \\
PAP $(\mu \mathrm{g} / \mathrm{L})$ & $5,200(3,400-7,600)$ & $13,000(9,400-20,000)$ & $17,000(11,000-24,000)$ \\
AT $(\%)$ & $45(38-52)$ & $43(33-51)$ & $39(30-48)$ \\
Fibrinogen $(\mathrm{g} / \mathrm{L})$ & $0.040(0.040-0.040)$ & $0.040(0.040-0.040)$ & $0.040(0.040-0.040)$ \\
$\mathrm{pHgb}(\mathrm{g} / \mathrm{dL})$ & $0.4(0.3-0.5)$ & $0.4(0.3-0.5)$ & $0.6(0.4-0.8)$ \\
FDP $(\mathrm{mg} / \mathrm{L})$ & $60(35-90)$ & $190(140-290)$ & $380(190-570)$ \\
C3bc $(\mathrm{AU} / \mathrm{mL})$ & $110(86-140)$ & $110(95-140)$ & $120(97-152)$ \\
TCC $(\mathrm{AU} / \mathrm{mL})$ & $63(51-84)$ & $110(86-140)$ & $150(120-230)$ \\
TNF- $\alpha(\mathrm{pg} / \mathrm{mL})$ & $44(36-64)$ & $43(32-60)$ & $40(29-50)$ \\
IL-6 $(\mathrm{pg} / \mathrm{mL})$ & $2,700(1,400-3,900)$ & $17,000(12,000-24,000)$ & $81,000(52,000-90,000)$
\end{tabular}

Values are given as median values with quartiles in parentheses. Heparin, Total plasma heparin; TAT, thrombin-antithrombin complex; $P F_{1.2}$, prothrombin fragment $1.2 ; \beta-T G, \beta$-thromboglobulin; PAP, plasmin- $\alpha_{2}$-antiplasmin complex; $A T$, antithrombin; $p H g b$, plasma free hemoglobin; $F D P$, D-dimer; $C 3 b c$, C3 activation products; $T C C$, terminal complement complex; $T N F$ - $\alpha$, tumor necrosis factor $\alpha$; IL-6, interleukin-6.

Table VI. Coagulation and fibrinolysis parameters in the circulating plasma in the study group $(n=40)$

\begin{tabular}{lcccccc}
\hline & \multicolumn{5}{c}{ Time points } \\
\cline { 2 - 6 } Analyses & Preop & End CPB & 1 h postop & 2 h postop & 4 h postop & 18 h postop \\
\hline Heparin $(\mathrm{IU} / \mathrm{mL})$ & $0.1(0.1-0.1)$ & $5(4-6)$ & $0.1(0.1-0.2)$ & $0.1(0.1-0.2)$ & $0.1(0.1-0.2)$ & $0.1(0.1-0.1)$ \\
$\mathrm{TAT}(\mu \mathrm{g} / \mathrm{L})$ & $3.5(2.6-5.7)$ & $31(21-41)$ & $26(21-36)$ & $45(30-120)$ & $110(57-180)$ & $24(16-38)$ \\
$\mathrm{PF}$ & $1.2(\mathrm{nmol} / \mathrm{L})$ & $2.5(1.7-3.0)$ & $3.2(2.3-4.5)$ & $4.4(3.4-6.8)$ & $6.8(4.9-9.9)$ & $2.9(2.0-4.7)$ \\
$\beta-\mathrm{TG}(\mathrm{IU} / \mathrm{mL})$ & $31(24-8-37)$ & $150(120-210)$ & $130(77-180)$ & $100(75-150)$ & $89(61-110)$ & $33(26-43)$ \\
Platelet count $\left(\times 10^{3} / \mathrm{mm}^{3}\right)$ & $182(160-240)$ & $160(130-210)$ & $180(150-220)$ & $190(170-230)$ & $190(160-240)$ & $180(160-220)$ \\
$\mathrm{PAP}(\mu \mathrm{g} / \mathrm{L})$ & $410(290-470)$ & $680(380-1200)$ & $760(600-960)$ & $850(650-1100)$ & $1200(890-1500)$ & $480(390-610)$ \\
$\mathrm{AT}(\%)$ & $100(92-100)$ & $65(59-73)$ & $91(82-100)$ & $98(88-100)$ & $100(89-100)$ & $100(96-100)$ \\
Fibrinogen $(\mathrm{g} / \mathrm{L})$ & $3.0(2.7-4.0)$ & $1.9(1.6-2.0)$ & $2.6(2.2-3.2)$ & $2.7(2.4-3.3)$ & $2.9(2.5-3.4)$ & $4.5(4.1-5.1)$ \\
$\mathrm{pHgb}(\mathrm{g} / \mathrm{dL})$ & $0(0-0.01)$ & $0.03(0.02-0.04)$ & $0.03(0.02-0.04)$ & $0.03(0.02-0.04)$ & $0.02(0.01-0.04)$ & $0(0-0.01)$ \\
\hline
\end{tabular}

Values are given as median values with quartiles in parentheses. Heparin, Total plasma heparin; TAT, thrombin-antithrombin complex; $P F_{1.2}$, prothrombin fragment $1.2 ; \beta$-TG, $\beta$-thromboglobulin; $P A P$, plasmin- $\alpha_{2}$-antiplasmin complex; $A T$, antithrombin; $p H g b$, plasma free hemoglobin.

Table VII. Inflammatory markers in the circulating plasma in the study group $(n=40)$

\begin{tabular}{lcccccc}
\hline & \multicolumn{5}{c}{ Time points } \\
\cline { 2 - 6 } Analyses & Preop & End CPB & 1 h postop & 2 h postop & 4 h postop & 18 h postop \\
\hline C3bc $(\mathrm{AU} / \mathrm{mL})$ & $9.0(7.5-11)$ & $52(39-69)$ & $79(58-110)$ & $49(30-78)$ & $21(16-33)$ & $8.0(6.0-10)$ \\
TCC $(\mathrm{AU} / \mathrm{mL})$ & $4.0(3.0-5.0)$ & $38(28-52)$ & $21(13-29)$ & $12(8.5-16)$ & $7.0(6.0-10)$ & $4.0(4.0-6.0)$ \\
TNF- $\alpha(\mathrm{pg} / \mathrm{mL})$ & $14(12-18)$ & $15(12-18)$ & $24(18-30)$ & $23(17-28)$ & $19(13-21)$ & $13(9.6-17)$ \\
$\mathrm{IL}-6(\mathrm{pg} / \mathrm{mL})$ & $6.2(4.5-8.6)$ & $23(16-29)$ & $140(120-180)$ & $240(160-360)$ & $240(160-360)$ & $300(220-390)$ \\
\hline
\end{tabular}

Values are given as median values with quartiles in parentheses. $C 3 b c$, C3 activation products; TCC, terminal complement complex; $T N F$ - $\alpha$, tumor necrosis factor $\alpha ; I L-6$, interleukin-6.

tion, and only small amounts of plasma free hemoglobin were detected (Table VI).

In the patients, total plasma heparin concentration reached a peak at the end of CPB (Table VI). Postoperative measurements indicated adequate reversal of anticoagulation with protamine.

The content of protein $\mathrm{C}$ in mediastinal shed blood varied between $37 \%$ and $94 \%$. Since the protein C assay would include both nonactivated as well as activated protein $\mathrm{C}$, the assay was also performed without protein $\mathrm{C}$ activator to measure the amount of pre-activated protein $\mathrm{C}$. Thus pre-activated protein $\mathrm{C}$ ranged from $0 \%$ to $30.5 \%$.

Concerning the immunologic system, the complement activation products and cytokines were highly elevated in the shed blood compared with the preoper- 
ative values in the patients (Tables V and VII). In particularly, the interleukin-6 increased continuously in the first postoperative hours, both in the shed blood and in the circulating plasma. The cytokine tumor necrosis factor $\alpha$ concentration in the mediastinal shed blood was approximately 3 times higher than the preoperative values in the patients.

Linear regression analysis revealed a statistical correlation between most of the patient plasma values measured 4 hours after the operation and the values in the mediastinal shed blood 2 hours after the operation (Table VIII).

Main group. The demographic and operative data are shown in Table I. The most relevant blood conservation parameters are displayed in Table II. Postoperative bleeding was moderate, and almost all mediastinal shed blood was autotransfused. In an extreme case as much as $5375 \mathrm{~mL}$ was returned to the patient without any harmful effects. Transfusion of allogeneic blood or blood products was seldom necessary $(3.5 \%)$, needed mainly in elderly women and patients reoperated on for bleeding. The hemoglobin concentrations were satisfactory in both groups at discharge from the hospital (Table II). Complications were few (Table III), and most of the patients were able to walk stairs or outside the hospital within 5 days after the operation. The overall hospital mortality was $0.44 \%$.

\section{Discussion}

Awareness of the risks of allogeneic transfusions is the main motivation for blood conservation after cardiac operations. A wide variety of blood conservation techniques has been developed and, apart from meticulous surgical techniques, the 2 principal approaches have been autotransfusion and hemostatic drug therapy. The present report deals with the influence of a simple perioperative autotransfusion protocol on the coagulation system, platelets, fibrinolysis, and the inflammatory response. The overall subsequent clinical consequences of the autotransfusion procedures were evaluated in a consecutive series of 4916 patients.

Intraoperative withdrawal of whole blood for retransfusion after CPB provides the immediate postoperative availability of fresh blood containing clotting factors, intact platelets, leukocytes, and red blood cells. ${ }^{4,16}$ This procedure has been shown to reduce postoperative bleeding and consequently allogeneic blood requirement and enhances hemodilution during CPB, which in turn reduces intraoperative hemoglobin loss. ${ }^{17}$ To our knowledge, no data so far have been available concerning potential activation of fresh blood stored at room temperature in the present setting. Except for some ele- vation of platelet $\beta$-TG, our study demonstrated absence of any activation of the biologic systems under investigation. These findings confirm the high quality of this pooled autologous blood.

The return of the CPB circuit blood immediately after $\mathrm{CPB}$ has in some studies proved to reduce the need for allogeneic transfusions, ${ }^{18}$ whereas others claim that this method contributes to postoperative bleeding problems and impairment of hemostasis. ${ }^{19}$ Although the residual volume in the extracorporeal circuit is assumed to reflect the state of the patient's blood at the end of $\mathrm{CPB}$, little information regarding the activation of this specific blood component has been published. Our study revealed some activation of coagulation, platelets, and fibrinolysis, as evidenced by moderately elevated levels of TAT complex, $\mathrm{PF}_{1.2}, \beta$ TG, and PAP complex when compared with preoperative values. Also, markers for inflammatory response were elevated. Except for the beneficial effects of autologous blood salvage, the true clinical effects of returning the residual circuit contents to the patients remain unclear. Certainly, the effects may be masked by the subsequent autotransfusion of the extensively more activated mediastinal shed blood.

Autotransfusion of postoperative mediastinal shed blood has been widely used for blood conservation during the past 2 decades. The safety and the blood salvage effects have been well documented, ${ }^{7-11}$ and return of the shed blood has been proved by the lack of septic, pulmonary, or hepatic complications. ${ }^{20}$ However, some authors have questioned the quality of the blood collected, and there have been indications of impaired hemostasis, ${ }^{21,22}$ and even disseminated intravascular coagulation in dogs, ${ }^{23}$ after autotransfusion of mediastinal shed blood.

Complete coagulation could be demonstrated as evidenced by the total absence of fibrinogen in the untreated, mediastinal shed blood. However, the present study could also demonstrate extremely high levels of markers for activation of both the coagulation and fibrinolytic systems, as well as for the inflammatory response. A statistically significant correlation was found between the elevations of these markers in the mediastinal shed blood and systemic plasma during the first postoperative hours. These indications of an extreme thrombin formation, with a reduced level of antithrombin and virtually no heparin present in the mediastinal shed blood, might suggest an insufficient clotting inhibition and, consequently, infusion of active thrombin during the autotransfusion procedure. The test for thrombin activity, however, was negative.

As no thrombin was found in the mediastinal shed blood, the measured pre-activated protein $\mathrm{C}$ ranging 
Table VIII. Linear regression analysis between the measured laboratory data from the study group $(n=40) 4$ hours postoperatively and the values in the mediastinal shed blood 2 hours postoperatively $(n=40)$

\begin{tabular}{lcc}
\hline Analysis & Correlation coefficient $(r)$ & P value \\
\hline TAT & 0.48 & $<.01$ \\
PF $_{1.2}$ & 0.42 & $<.01$ \\
$\beta-T G$ & 0.58 & $<.001$ \\
PAP & 0.32 & $<.05$ \\
AT & 0.68 & $<.001$ \\
pHgb & -0.11 & $>.2$ \\
Heparin & 0.29 & $<.1$ \\
C3bc & 0.66 & $<.001$ \\
TCC & 0.23 & $<.2$ \\
TNF- $\alpha$ & 0.43 & $<.01$ \\
IL-6 & 0.15 & $>.2$ \\
\hline
\end{tabular}

$T A T$, Thrombin-antithrombin complex; $P F_{1.2}$, prothrombin fragment $1.2 ; \beta$ $T G, \quad \beta$-thromboglobulin; $P A P$, plasmin- $\alpha_{2}$-antiplasmin complex; $A T$, antithrombin; $p H g b$, plasma free hemoglobin; heparin, total plasma heparin; $C 3 b c$, C3 activation products; TCC, terminal complement complex; TNF- $\alpha$, tumor necrosis factor $\alpha ; I L-6$, interleukin-6.

from $0 \%$ to $30.5 \%$ might have been activated in the circulation. Other studies also indicate this mechanism. ${ }^{7,8}$ The presence of protein $\mathrm{C}$ ranging between $37 \%$ and $94 \%$ in shed blood during the postoperative time might add to the safety of the autotransfusion of mediastinal shed blood. The presence of protein $\mathrm{C}$ in shed blood has also been reported by others, even in higher concentrations than in bank blood. ${ }^{8}$ The return of both TAT complex and $\mathrm{PF}_{1.2}$ to nearly preoperative levels 18 hours after the operation, despite continuous autotransfusion during this time, supports the safety of this practice.

A strong platelet activation was also evident, as highly elevated levels of $\beta$-TG were seen in the shed blood after the operation, about 35 times the systemic concentration at the end of CPB. This correlated well with the elevations seen in patient plasma during the first postoperative hours. No clinical hemostatic consequences could be demonstrated. Despite the very high levels of fibrinolytic parameters in the shed blood, like PAP complex and D-dimer, disturbing bleeding problems were rare. This is reflected in an acceptable amount of postoperative drainage (median $650 \mathrm{~mL}$ ) in the total patient population.

In accordance with other investigators, ${ }^{6,8}$ the mediastinal shed blood in this study contained increased levels of plasma free hemoglobin. This is probably mainly due to mechanical damage of red blood cells during $\mathrm{CPB},{ }^{20}$ but may also be partly due to activation of the complement system during and after the operation. ${ }^{6}$ On the other hand, others have demonstrated that exposure of shed blood to the cardiotomy reservoir does not exacerbate blood cell damage, as survival of red blood cells from mediastinal shed blood after autotransfusion is comparable with the survival of red blood cells in the patients' circulating blood. ${ }^{24}$ In the present study, no statistically significant correlation could be registered between the plasma free hemoglobin concentration in the patients and in the mediastinal shed blood. It should further be borne in mind that bank blood also contains high levels of free hemoglobin after normal storage. ${ }^{25}$

As for the immunologic system, both the residual content of the CPB circuit and particularly the mediastinal shed blood contained large amounts of cytokines and complement activation products. The consequences of retransfusion of these markers remain unclear. Although release of cytokines and activation of the complement cascade are known to take part in the inflammatory response during and after CPB operations, ${ }^{26}$ there were no clinical signs of unexpected organ failure. In the total patient population, the median time on postoperative ventilatory support was 1.5 hours, and incidents of postoperative renal failure were rare. Tumor necrosis factor $\alpha$ has further been shown to impair wound healing over time by directly suppressing collagen synthesis and collagen gene expression. ${ }^{27}$ There were no clinical correlating signs or symptoms, which is partly reflected in a low infection rate. A normalization of the plasma concentrations of the inflammatory markers occurred on the first postoperative day, although autotransfusion was consistently performed during the entire period. It might be suggested that regulatory mechanisms may effectively neutralize the infusion of these components, at least in patients with normal renal function.

Despite the extensive alterations in the autotransfused blood regarding thrombin formation, platelet activity, fibrinolytic activity, and activation of the immunologic system, the clinical effects of autotransfusion should be evaluated in larger patient series. On the basis of rather limited numbers of patients, some authors have questioned the benefit of autotransfusion, suggesting either increased bleeding tendency ${ }^{21}$ or lacking reduction in postoperative blood loss or requirements for allogeneic transfusions. ${ }^{28}$ However, the present experience with nearly 5000 consecutive patients undergoing coronary bypass with a consistent autotransfusion protocol could demonstrate a high level of safety without any significant transfusion-related side-effects, as well as an allogeneic transfusion rate of less than $4 \%$.

In conclusion, the present investigation indicates that 
the autologous blood removed before CPB was close to non-activation, whereas the content of the CPB circuit was moderately activated and the mediastinal shed blood excessively activated regarding coagulation, platelets, fibrinolysis, and immunologic response. However, retransfusion of all these available autologous blood resources to a large patient population did not carry any clinical disadvantages or harmful effects. The need for allogeneic blood products was minimal, with preservation of an adequate hemoglobin concentration. Thus the present data clearly indicate a major disparity between laboratory tests and clinical performance.

We thank Michel Abdelnoor, $\mathrm{PhD}$, for skillful statistical assistance, and Tom Eirik Mollnes, $\mathrm{MD}, \mathrm{PhD}$, for performing the complement analyses.

\section{REFERENCES}

1. Slater NG. Autologous blood transfusion today. Br J Clin Pract 1992;46:193-7.

2. Murphy PJ, Connery C, Hicks GL Jr, Blumberg N. Homologous blood transfusion as a risk factor for postoperative infection after coronary artery bypass graft operations. J Thorac Cardiovasc Surg 1992;104:1092-9.

3. Owings DB, Kruskall MS, Thurer RL, Donovan LM. Autologous blood donations prior to elective cardiac surgery: safety and effect on subsequent blood use. JAMA 1989;262:1963-8.

4. Kochamba GS, Pfeffer TA, Sintek CF, Khonsari S. Intraoperative autotransfusion reduces blood loss after cardiopulmonary bypass. Ann Thorac Surg 1996;61:900-3.

5. Sutton RG, Kratz JM, Spinale FG, Crawford FA Jr. Comparison of three blood-processing techniques during and after cardiopulmonary bypass. Ann Thorac Surg 1993;56:938-43.

6. Kongsgaard UE, Tølløfsrud S, Brosstad F, Øvrum E, Bjørnskau L. Autotransfusion after open heart surgery: characteristics of shed mediastinal blood and its influence on the plasma proteases in circulating blood. Acta Anaesthesiol Scand 1991;35:71-6.

7. Hartz RS, Smith JA, Green D. Autotransfusion after cardiac operation: assessment of hemostatic factors. J Thorac Cardiovasc Surg 1988;96:178-82.

8. Axford TC, Dearani JA, Ragno G, MacGregor H, Patel MA, Valeri CR, et al. Safety and therapeutic effectiveness of reinfused shed blood after open heart surgery. Ann Thorac Surg 1994; 57:615-22.

9. Schmidt H, Mortensen PE, Følsgaard SL, Jensen EA. Autotransfusion after coronary artery bypass grafting halves the number of patients needing blood transfusion. Ann Thorac Surg 1996;61:1177-81.

10. Øvrum E, Åm Holen E, Tangen G. Consistent non-pharmacologic blood conservation in primary and reoperative coronary artery bypass grafting. Eur J Cardiothorac Surg 1995;9:30-5.

11. Øvrum E, Åm Holen E, Abdelnoor M, Øystese R. Conventional blood conservation techniques in 500 consecutive artery bypass operations. Ann Thorac Surg 1991;52:500-5.
12. Clauss A. Gerinnungsphysiologische Schnellmetode zur Bestimmung des Fibrinogens. Acta Haematol 1957;17:237-46.

13. Hunter FT, Grove-Rasmussen M, Soutter L. A spectrophotometric method for quantitating hemoglobin in plasma or serum. Am J Clin Pathol 1950;20:429-33.

14. Mollnes TE, Lea T, Frøland SS, Harboe M. Quantification of the terminal complement complex in human by an enzymelinked immunosorbent assay based on monoclonal antibodies against a neoantigen of the complex. Scand J Immunol 1985;22: 197-202.

15. Garred P, Mollnes TE, Lea T. Quantification in enzyme-linked immunosorbent assay of a $\mathrm{C} 3$ neoepitope expressed on activated human complement factor C3. Scand J Immunol 1988;27:329-35.

16. Schönberger JPAM, Bredée JJ, Tjian D, Everts PAM, Wildevuur $\mathrm{CRH}$. Intraoperative predonation contributes to blood saving. Ann Thorac Surg 1993;56:893-8.

17. Cooper JR Jr, Slogoff S. Hemodilution and priming solutions for cardiopulmonary bypass. In: Gravlee GP, Davies RF, Utley JR, ed. Cardiopulmonary bypass: principles and practice. Baltimore: Williams \& Wilkins; 1993. p. 124-37.

18. Dietrich W, Barankay A, Dilthey G, Mitto H-P, Richter JA. Reduction of blood utilization during myocardial revascularization. J Thorac Cardiovasc Surg 1989;97:213-9.

19. De Haan J, Boonstra PW, Monnink SHJ, Ebels T, van Oeveren W. Retransfusion of suctioned blood during cardiopulmonary bypass impairs hemostasis. Ann Thorac Surg 1995;59:901-7.

20. Thurer RL, Lytle BW, Cosgrove DM, Loop FD. Autotransfusion following cardiac operations: a randomized, prospective study. Ann Thorac Surg 1979;27:500-7.

21. De Haan J, Schönberger J, Haan J, van Oeveren W, Eijgelaar A. Tissue-type plasminogen activator and fibrin monomers synergistically cause platelet dysfunction during retransfusion of shed blood after cardiopulmonary bypass. J Thorac Cardiovasc Surg 1993;106:1017-23.

22. Schönberger JPAM, van Oeveren W, Bredée JJ, Everts PAM, de Haan J, Wildevuur CRH. Systemic blood activation during and after autotransfusion. Ann Thorac Surg 1994;57:1256-62.

23. Stillman RM, Wrezlewicz WW, Stanczewski B, Chapa L, Fox MJ, Sawyer PN. The haematological hazards of autotransfusion. Br J Surg 1976;63:651-4.

24. Schmidt H, Lund JO, Nielsen SL. Autotransfused shed mediastinal blood has normal erythrocyte survival. Ann Thorac Surg 1996;62:105-8.

25. Glover JL, Smith R, Yaw P, Radigan LR, Plawecki R, Link W. Intraoperative autotransfusion: an underutilized technique. Surgery 1976;80:474-9.

26. Kirklin JK, Westaby S, Blackstone EH, Kirklin JW, Chenoweth DE, Pacifico AD. Complement and the damaging effects of cardiopulmonary bypass. J Thorac Cardiovasc Surg 1983;86: 845-57.

27. Salomon GD, Kasid A, Cromack DT, Director E, Talbot TL, Sank A, et al. The local effects of cachectin/tumor necrosis factor on wound healing. Ann Surg 1991;214:175-80.

28. Bouboulis N, Kardara M, Kesteven PJ, Jayakrishnan AG. Autotransfusion after coronary artery bypass surgery: Is there any benefit? J Card Surg 1994;9:314-21. 